\title{
Correlation Coefficient and Path Coefficient in Field pea (Pisum sativum L.)
}

\author{
Akanksha Srivastava, Aarti Sharma*, Tejasvi Singh and Rajesh Kumar \\ Department of Genetics and Plant Breeding, Narendra Deva University of Agriculture and \\ Technology, Faizabad-224 229, UP, India \\ *Corresponding author
}

\section{A B S T R A C T}

\section{Keywords}

Field pea,

Correlation,

Germplasm, Direct effect

Article Info

Accepted:

07 January 2018

Available Online:

10 February 2018
In total of 113 genotypes including three check varieties, a wide range of variability for different characters had been observed and comparison of means of genotypes using least significant differences, indicated existence of very high degree of variability for all the characters in the germplasm collection. The following five genotypes exhibited high mean performance for seed yield/plant were IP-2K-84, EC-356166, HUDP-27, DMR-15, IPFD2-6. Seed yield per plant exhibited highly significant and positive correlation with 100 seed weight $(0.3775)$, number of pods/plant $(0.3524)$, harvest index $(0.3270)$, number of seeds/pod (0.3262) and biological yield ( $g$ ) (0.2828). The occurrence of negative as well as positive indirect effects on yield by one or another character presents a complex situation where a compromise balance is required to attain proper balance of different yield components, for determining the ideotype of seed yield in field pea. The highest positive direct effect on seed yield per plant was exerted by harvest index $(0.7902)$ followed by biological yield (g) (0.7820), 100 seed weight (0.3406), number of seeds per pod $(0.2788)$ and number of pods per plant (0.2622).

\section{Introduction}

Field pea is legume crop, grown in rabi season. Its fresh pods are eaten as vegetable which is also a rich source of protein (15.50$39.7 \%$ ) (Thaler and Stein, 2003). Despite of inherent high productivity potential of pea, the production has been on decline and average productivity is miserably low due to nonavailability of input responsive multiple disease resistant high yielding varieties having resistance to high temperature at reproductive phase. These details about current status of pea production in India, alarms an urgent need to evolve high yielding varieties having high protein content, resistance to biotic and abiotic stresses coupled with suitability for different agro-climatic conditions and cropping systems. With cognizance of aforementioned situations, germplasm evaluation has been done for variability via studying correlation and path analysis in pea has been carried out based on testing 110 genotypes as major objectives of this experiment. Dixit et al., (2002) reported that seed yield per plant was positively and significantly associated with pods per plant, harvest index and primary branches per plant. The amount of variation present for character in the breeding materials, broaden its scope for improvement through 
selection. Mishra et al., (2014) had studied genetic variability for yield and seed vigor characters in field pea. Path-coefficient analysis is a tool to partition the observed correlation into direct and indirect effects of yield components on seed yield, which provide clearer picture of character association for formulating efficient selection strategy. Arya et al., (2004) reported that grain yield was significantly and positively correlated with number of nodes and plant height. The objective of the study was to screen the germplasm available in the experiment in a way to find genetically diverse genotypes which can be used further in various breeding program in developing high yielding varieties.

\section{Materials and Methods}

The experiment was conducted to evaluate 113 genotype lines including three checks viz., Ambika, Rachna, and HFP-4, under irrigated normal soil condition in Augmented Block Design. The entire experimental field was divided into 11 blocks of equal size and each block had 13 plots. Out of 13 plots in a block, 10 plots were used for accommodating the test genotypes. The three checks were randomly allocated along with the test genotypes in a block. Each plot was consisted of single row of $4 \mathrm{~m}$ length, following inter and intra row spacing of $30 \mathrm{~cm}$ and $5 \mathrm{~cm}$, respectively. Recommended cultural practices were practiced to raise a good crop. The analysis of variance for different characters in Augmented Block Design was done according to Federer (1956). The simple correlations between different characters at genotypic (g) and phenotypic (p) levels were estimated as below according to Searle (1961). Path coefficient analysis was carried out according to Dewey and $\mathrm{Lu}$ (1959). For calculating, the genotypic and phenotypic correlation coefficients for all possible combination the formula suggested by Johnson et al., (1955) and Hanson et al., (1956) were adopted. Five competitive plants from each plot were randomly selected for recording observations on all the 10 metric traits, except days to 50 per cent flowering and days to maturity, which was recorded on the plot basis.

\section{Results and Discussion}

Estimate of the simple correlation coefficient among the ten characters of field pea genotypes are presented in Table 1. At phenotypic level, seed yield per plant exhibited highly significant and positive correlation with 100 seed weight (0.3775), number of pods/plant $(0.3524)$, harvest index (0.3270), number of seeds/pod(0.3262) and biological yield(g) (0.2828) same results were found by Amar Jeet Gupta et al., (2007). The non-significant but positive correlation of seed yield was recorded with the days to $50 \%$ flowering (0.1482), plant height (0.1330), days to maturity $(0.0625)$ with no. of pods/plant (0.0325). Plant height showed highly significant and positive association with primary branches/plant (0.2559), number of seeds/pod (0.5693) and is significant and positively correlated with biological yield/plant (0.2318) whereas it is nonsignificant and positively correlated with days to maturity (0.0607). However, negative and significant association of plant height was shown with 100 seed weight (-0.2267). Plant height showed non-significant and negative correlation with days to $50 \%$ flowering ($0.0026)$, harvest index (-0.1225). Days to $50 \%$ flowering exhibited highly significant and positive correlation with days to maturity(0.6896) and it also showed nonsignificant and positive correlation with primary branches/plant (0.1594), 100 seed weight (0.1257), harvest index (0.0010), whereas it was non-significantly and negatively correlated with no. of pods/plant ($0.1264)$, seeds/pod (-0.0258) and biological yield/plant (-0.0285). Days to maturity showed non-significant and positive 
correlation with primary branches/plant (0.1104), 100 seed weight (0.1168) and biological yield/plant (0.0494) and nonsignificant and negative correlation with no. of pods/plant (-0.1352), no. of seeds/pod ($0.0526)$ and harvest index (-0.1162).

Primary branches showed highly significant and positive correlation with biological yield $(0.2580)$ and it also showed highly significant and negative correlation with harvest index (0.2615 ). It showed non-significant but positive association with number of seeds/pod (0.1775) and non-significant and negative correlation with number of pods/plant (-0.1625) and 100 seed weight (-0.0583). Number of pods/plant showed significant and positive correlation with harvest index (0.2174) and nonsignificant and positive association with biological yield/plant (0.0041) but it also showed non-significant and negative correlation with seeds/pod (-0.0358) and 100 seed weight (-0.1468). Number of seeds/pod showed highly significant but negative correlation with 100 seed weight $(-0.3671)$ and it was non-significant but positively correlated with biological yield (0.1041) and harvest index (0.1352). The 100 seed weight showed non-significant but positive correlation with biological yield/plant $(0.1362)$ and harvest index (0.0623) while the biological yield/plant showed highly significant but negative correlation with harvest index (-0.7302).

Table.1 Simple correlation coefficients between different characters in genotypes of field pea (Pisum sativum L.)

\begin{tabular}{|c|c|c|c|c|c|c|c|c|c|c|c|}
\hline $\begin{array}{l}\text { S. } \\
\text { No. }\end{array}$ & Characters & $\begin{array}{l}\text { Plant } \\
\text { height } \\
\text { (cm) }\end{array}$ & $\begin{array}{l}\text { Days to } \\
50 \% \\
\text { flowering }\end{array}$ & $\begin{array}{l}\text { Days to } \\
\text { maturity }\end{array}$ & $\begin{array}{l}\text { Primary } \\
\text { branches/ } \\
\text { plant }\end{array}$ & $\begin{array}{l}\text { Number } \\
\text { of } \\
\text { pods/plant }\end{array}$ & $\begin{array}{l}\text { No. of } \\
\text { seeds/ } \\
\text { pod }\end{array}$ & $\begin{array}{l}100 \text { Seed } \\
\text { weight }\end{array}$ & $\begin{array}{l}\text { Biological } \\
\text { yield/plant }\end{array}$ & $\begin{array}{l}\text { Harvest } \\
\text { Index } \\
(\%)\end{array}$ & $\begin{array}{l}\text { Grain } \\
\text { yield } \\
\text { /plant (g) }\end{array}$ \\
\hline 1. & $\begin{array}{l}\text { Plant } \\
\text { height }(\mathrm{cm})\end{array}$ & $\begin{array}{c}1.000 \\
0\end{array}$ & -0.0026 & 0.0607 & $0.2559 * *$ & -0.1134 & $0.5693 * *$ & $-0.2267 *$ & $0.2318 *$ & -0.1225 & 0.1330 \\
\hline 2. & $\begin{array}{l}\text { Days to } 50 \% \\
\text { flowering }\end{array}$ & & 1.0000 & $0.6896 * *$ & 0.1594 & -0.1264 & -0.0258 & 0.1257 & -0.0285 & 0.0010 & 0.1482 \\
\hline 3. & $\begin{array}{l}\text { Days to } \\
\text { maturity }\end{array}$ & & & 1.0000 & 0.1104 & -0.1352 & -0.0526 & 0.1168 & 0.0494 & -0.1162 & 0.0625 \\
\hline 4. & $\begin{array}{l}\text { Primary } \\
\text { Branches/plant }\end{array}$ & & & & 1.0000 & -0.1625 & 0.1775 & -0.0583 & $0.2580 * *$ & ${ }_{0 .}^{-}$ & 0.0325 \\
\hline 5. & $\begin{array}{l}\text { Number of } \\
\text { pods/plant }\end{array}$ & & & & & 1.0000 & -0.0358 & -0.1468 & 0.0041 & $0.2174 *$ & $0.3524 * *$ \\
\hline 6. & $\begin{array}{l}\text { Number of } \\
\text { seeds/ pod }\end{array}$ & & & & & & 1.0000 & $\begin{array}{c}- \\
0.3671 * *\end{array}$ & 0.1041 & 0.1352 & $0.3262 * *$ \\
\hline 7. & $\begin{array}{l}100 \text { Seed } \\
\text { weight }(\mathrm{g})\end{array}$ & & & & & & & 1.0000 & 0.1362 & 0.0623 & $0.3775 * *$ \\
\hline 8. & $\begin{array}{l}\text { Biological } \\
\text { yield/ plant }(\mathrm{g})\end{array}$ & & & & & & & & 1.0000 & $\stackrel{-}{-}-7302 * *$ & $0.2828 * *$ \\
\hline 9. & $\begin{array}{l}\text { Harvest index } \\
(\%)\end{array}$ & & & & & & & & & 1.0000 & $0.3270 * *$ \\
\hline 10. & $\begin{array}{l}\text { Grain } \\
\text { yield/plant(g) }\end{array}$ & & & & & & & & & & 1.0000 \\
\hline
\end{tabular}


Table.2 Direct and indirect effects of different characters on seed yield per plant in genotypes of field pea (Pisum sativum L.)

\begin{tabular}{|c|c|c|c|c|c|c|c|c|c|c|}
\hline Characters & $\begin{array}{c}\text { Plant } \\
\text { height }(\mathrm{cm})\end{array}$ & $\begin{array}{c}\mathbf{5 0 \%} \\
\text { Flowering }\end{array}$ & $\begin{array}{l}\text { Days to } \\
\text { maturity }\end{array}$ & $\begin{array}{c}\text { Primary } \\
\text { branches/ } \\
\text { plant }\end{array}$ & $\begin{array}{l}\text { Pods/ } \\
\text { plant }\end{array}$ & $\begin{array}{l}\text { Seeds/ } \\
\text { pod }\end{array}$ & $\begin{array}{c}\text { Test } \\
\text { weight (g) }\end{array}$ & $\begin{array}{l}\text { Biological } \\
\text { yield (g) }\end{array}$ & $\begin{array}{l}\text { Harvest } \\
\text { index }(\%)\end{array}$ & $\begin{array}{l}\text { Grain } \\
\text { yield (g) }\end{array}$ \\
\hline $\begin{array}{l}\text { Plant } \\
\text { height }(\mathrm{cm})\end{array}$ & -0.0111 & 0.0000 & -0.0007 & -0.0028 & 0.0013 & -0.0063 & 0.0025 & -0.0026 & 0.0014 & 0.1330 \\
\hline $\begin{array}{l}50 \% \\
\text { Flowering }\end{array}$ & -0.0004 & 0.1480 & 0.1021 & 0.0236 & -0.0187 & -0.0038 & 0.0186 & -0.0042 & 0.0001 & 0.1482 \\
\hline $\begin{array}{l}\text { Days to } \\
\text { maturity }\end{array}$ & 0.0013 & 0.0149 & 0.0216 & 0.0024 & -0.0029 & -0.0011 & 0.0025 & 0.0011 & -0.0025 & 0.0625 \\
\hline $\begin{array}{l}\text { Primary } \\
\text { branches/ } \\
\text { plant }\end{array}$ & 0.0070 & 0.0043 & 0.0030 & 0.0272 & -0.0044 & 0.0048 & -0.0016 & 0.0070 & -0.0071 & 0.0325 \\
\hline Pods/ plant & -0.0297 & -0.0331 & -0.0354 & -0.0426 & 0.2622 & -0.0094 & -0.0385 & 0.0011 & 0.0570 & 0.3524 \\
\hline Seeds/ pod & 0.1587 & -0.0072 & -0.0147 & 0.0495 & -0.0100 & 0.2788 & -0.1023 & 0.0290 & 0.0377 & 0.3262 \\
\hline Test weight (g) & -0.0772 & 0.0428 & 0.0398 & -0.0199 & -0.0500 & -0.1250 & 0.3406 & 0.0464 & 0.0212 & 0.3775 \\
\hline $\begin{array}{l}\text { Biological } \\
\text { yield }(\mathrm{g})\end{array}$ & 0.1813 & -0.0223 & 0.0386 & 0.2018 & 0.0032 & 0.0814 & 0.1065 & 0.7820 & -0.5710 & 0.2828 \\
\hline $\begin{array}{l}\text { Harvest index } \\
(\%)\end{array}$ & -0.0968 & 0.0008 & -0.0918 & -0.2066 & 0.1718 & 0.1069 & 0.0493 & -0.5770 & 0.7902 & 0.3270 \\
\hline
\end{tabular}

Residual effect $=0.4311 ;$ Bold figures indicate the direct effects

Path coefficient analyses were estimated on phenotypic as well as genotypic levels to resolve the direct and indirect effects of different characters on seed yield as presented in Table 2. At phenotypic level the highest positive direct effect on seed yield per plant was exerted by harvest index $(0.7902)$ followed by biological yield (g) (0.7820), 100 seed weight (0.3406), number of seeds per pod (0.2788) and number of pods per plant $(0.2622)$. Whereas very low positive and direct effect was recorded by days to maturity (0.0261). Direct effect in negative direction was exerted by the plant height (-0.0111).

This indicated that direct contribution of these traits was too low to be considered by any consequences. Highly positive indirect effects on seed yield per plant is exerted by biological yield per plant $(0.2018)$ via primary branches per plant. However, days to maturity $(-0.0025)$, number of primary branches/plant (-0.0071) and biological yield/plant (-0.5710), had a negative indirect effect via harvest index. The remaining estimates of the analysis were too low to be considered. The estimate of residual effect $(0.4311)$ and $R^{2}(0.8141)$ is positive.
In present study a strong and positive association of seed yield per plant observed with 100 seed weight, number of pods/plant, harvest index, number of seeds/pod and biological yield. The non-significant but positive correlation of seed yield was recorded with the days to $50 \%$ flowering, plant height, days to maturity with no. of pods/plant i.e. these characters showed weak association with seed yield per plant in positive direction. Thus, these characters emerged as most vital component traits and associated positively with seed yield per plant. The genotypic correlation coefficient between different characters was generally similar in sign and nature to the corresponding phenotypic correlation coefficients in the experiment as found by Tyagi et al., (2012) and Pooja Pandey et al., (2015) also. However in general, genotypic correlation coefficient were higher in magnitude from the corresponding phenotypic correlation coefficient values. Similar, results have been reported by Mahant et al., (2001), Arya et al., (2004) and Kumar et al., (2003).

High positive direct contribution to seed yield per plant was exhibited by harvest index and biological yield per plant. However, plant 
height, number of primary branches per plant and 100-seed weight exhibited positive considerable direct effect on seed yield per plant. Patel et al., (2006) also reported positive correlation between seed yield per plant with number of pods per plant, number of branches per plant, pod length, days to maturity and shelling percentage at genotypic and phenotypic level. Ghobary (2010) also obtained results that revealed; important yield components effect directly like biological yield, harvest index, number of primary branches per plant and 100seed weight.

\section{References}

Akhilesh Kumar Pal and Shivendra Singh 2012. Correlation and path analysis in garden pea (Pisum sativum L. var. Hortense). T. Asian J. Horti., 7(2): 569-573.

Amar Jeet Gupta, Y. V. Singh, B. K. Singht and K. Hussain 2007. Correlation studies in garden pea (Pisum sativum L.). T. horti. J.20 (2): 87-90.

Arya, Satyawan; Malik, B.P.S; Kumar, Ram and Dhari, Ram 2004. Variability, correlation and path analysis in field pea (Pisum sativum L.). Haryana Agric. Univ. J. of Res, 34(2): 149-53.

Dewey, D.K. and Lu, K.H. 1952. A correlation and path coefficient analysis of components of crested wheat grass and production. Agron. J., 51: 515-518.

Dixit, G.P.; Singh, I.P. and Khare, A.P. 2002. Genetic divergence study in field pea (Pisum sativum L.). Legume Res., 25 (3), 199-201.

Federer, W.T. 1956. Augmented designs. Hawaiian Planters Record, 55: 191-208.

Ghobary, H. M.M. 2010. Study of relationship between yield and some yield components in garden pea (Pisum sativum
L.) by using correlation and path analysis. J. Agric. Res., 36:351-360.

Hanson, G.H., Robinson, H.F. and Comstock, R.E. 1956. Biometrical studies on yield and segregating population of Korean Lespedeza. Agron. J., 48: 268-271.

Johnson, H.W., Robinson, H.F. and Comstock, R.E. 1955. Estimation of genetic and environmental variability in soybean. Agron. J., 47: 314-318.

Kumar, B.; Ram, L; Singh, J.D. and Singh, B. 2003.Correlations and path coefficient analysis in pea (Pisum sativum L.). Prog. Agric., 3 (1/2), 141-142.

Mahant, I.C; Senapati, N; Samal, K.M and Dhal, A. 2001. Genetic variability performance, character association and co-heritability in field pea (Pisum sativum L.). Legume Res., 24 (2):92-96.

Patel, P.J.; Patel, N.H.; Prajapati, B.H.; Tikka, S.B.S. and Patel, P.T. 2006. Correlation and path-analysis in field pea (Pisum sativum L.). Indian J. of Pulses Res., 19 (1): 109-110.

Pooja Pandey Neeraj Singh and Monisha Rawat (2015): Study of genetic variation, heritability and correlation in vegetable pea (Pisum sativum L.) The Bioscan 10(4): 2131-2133.

Searle, S.R. 1961. Phenotypic, Genotypic and Environmental correlations, Biometrics, 17: 474-480.

Thaler, R. A. and Stein, H. H. 2003. Using South Dakota grown field peas in swine diets. Extension Extra 2041, South Dakota State University.

Tyagi, N., Singh, A. K., Rai, V. P., Kumar, S. and Srivastava, C. P. 2012. Genetic variability studies for lodging resistance and yield attributes in pea (Pisum sativum L.). J. Food Leg. 25(3): 179-182.

\section{How to cite this article:}

Akanksha Srivastava, Aarti Sharma, Tejasvi Singh and Rajesh Kumar. 2018. Correlation Coefficient and Path Coefficient in Field Pea (Pisum sativum L.). Int.J.Curr.Microbiol.App.Sci. 7(02): 549-553. doi: https://doi.org/10.20546/ijcmas.2018.702.069 